Canadian University Music Review

Revue de musique des universités canadiennes

\title{
Introduction to Man and Music/Music and Society Series, Part II
}

Paul F. Rice

Volume 16, numéro 2, 1996

URI : https://id.erudit.org/iderudit/1014429ar

DOI : https://doi.org/10.7202/1014429ar

Aller au sommaire du numéro

Éditeur(s)

Canadian University Music Society / Société de musique des universités

canadiennes

ISSN

0710-0353 (imprimé)

2291-2436 (numérique)

Découvrir la revue

\section{Citer ce document}

Rice, P. F. (1996). Introduction to Man and Music/Music and Society Series, Part II. Canadian University Music Review / Revue de musique des universités

canadiennes, 16(2), 118-118. https://doi.org/10.7202/1014429ar

All Rights Reserved (C Canadian University Music Society / Société de musique des universités canadiennes, 1996
Ce document est protégé par la loi sur le droit d'auteur. L’utilisation des services d'Érudit (y compris la reproduction) est assujettie à sa politique d'utilisation que vous pouvez consulter en ligne.

https://apropos.erudit.org/fr/usagers/politique-dutilisation/ 


\section{REVIEWS/COMPTES RENDUS}

\section{Introduction to Man and Music/Music and Society Series, Part II}

We continue with the series of reviews devoted to the volumes of the Man and Music/Music and Society series (general editor, Stanley Sadie) that was begun in the previous volume of this journal. As noted at that time, the books are a supplement to the television programmes called "Man and Music," which were produced by Granada TV in the United Kingdom in the mid-1980s. The publication of the books has followed in random order, and the series has only recently been completed.

During the past ten years there have been significant changes in the way that musicologists approach the study of music, as well as significant gains made in our knowledge of early repertoires. As will be seen below, reviewers report that some of the earlier volumes now appear dated, and already need revision. Furthermore, I am pleased that several of our reviewers have questioned the lack of specific Canadian content in the series. We have a musical heritage of which we can be proud; it should be recognized by those outside of this country.

Paul F. Rice

Iain Fenlon, ed. The Renaissance: From the 1470s to the End of the 16th Century. Music and Society. Englewood Cliffs, N.J.: Prentice Hall, 1989. x, 418 pp. ISBN 0-13-773409-3 (hardcover), ISBN 0-13-036161-5 (softcover).

1. Iain Fenlon, "Music and Society"; 2. Christopher Reynolds, "Rome: a City of Rich Contrast"; 3. Iain Fenlon, "Venice: Theatre of the World"; 4. William F. Prizer, "North Italian Courts, 1460-1540"; 5. Allan W. Atlas, "Aragonese Naples"; 6. Richard Freedman, "Paris and the French Court under François I"; 7. Frank Dobbins, "Lyons: Commercial and Cultural Metropolis"; 8. Martin Picker, "The Habsburg Courts in the Netherlands and Austria, 1477-1530"; 9. James Haar, "Munich at the Time of Orlande de Lassus"; 10. Robin A. Leaver, "The Lutheran Reformation"; 11. Susan Gattuso, "16th-Century Nuremberg"; 12. Craig Monson, "Elizabethan London"; 13. Tess Knighton, "The Spanish Court of Ferdinand and Isabella"; 14. Kristine K. Forney, "16th-Century Antwerp."

A review at this time of a book published in 1989 might more honestly call itself a retrospective. This is especially true given the rapid evolution of the societally-oriented "New Musicology" over the past few years. ${ }^{1}$ A number of

1 For a discussion of this phenomenon, see Ellen Rosand, "The Musicology of the Present," AMS Newsletter 25, no. 1 (1995): 10-11, 15. 